\title{
Spatial and Temporal Changes of Groundwater Level Induced by Thrust Faulting
}

\author{
Yeeping Chia, ${ }^{1}$ Jessie J. Chiu, ${ }^{2}$ Yi-Hsuan Chiang, ${ }^{1}$ Tsai-Ping Lee, ${ }^{1}$ and Chen-Wuing Liu ${ }^{3}$
}

\begin{abstract}
Changes of groundwater level, ranging from a fall of $11.10 \mathrm{~m}$ to a rise of $7.42 \mathrm{~m}$, induced by thrust faulting during the $1999 \mathrm{M}_{\mathrm{w}}$ 7.6, Chi-Chi earthquake have been recorded in 276 monitoring wells in Taiwan. Most coseismic falls appeared near the seismogenic fault as well as other active faults, while coseismic rises prevailed away from the fault. Coseismic groundwater level rises and falls correlated fairly well with hypocentral distance in the vicinity of the thrust fault. We found a major difference of coseismic changes in wells of different depths at most multiple-well stations. The recovery process of coseismic groundwater level changes is associated with the confining condition of the aquifer. Cross-formational flow is likely to play an important role in groundwater level changes after the earthquake. In the hanging wall of the thrust fault, an abnormal decline of groundwater level was observed immediately before the earthquake. The underlying mechanism of the unique preseismic change warrants further investigation.
\end{abstract}

Key words: Groundwater, Chi-Chi earthquake, Thrust fault, Coseismic, Postseismic, Preseismic.

\section{Introduction}

Water level in a well-confined aquifer could be sensitive to crustal strain (BREDEHOEFT, 1967). Field observations have shown a correlation between the estimated tectonic strains and the coseismic changes of well water level during the 1974 Izu-HantoOki earthquake (WAKITA, 1975). Variations of groundwater level in seismic regions have been used to monitor crustal deformation and to search for an earthquake precursor (BAKUn and Lindh, 1985; Kissin et al., 1996).

Coseismic groundwater level changes have been reported in many places around the world (Montgomery and Manga, 2003), however most changes are either sparsely distributed or concentrated in a few spots. Postseismic changes may reflect the subsurface flow in response to coseismic changes or permeability changes (RoELOFFS, 1998; WANG et al., 2004). The observation of the flow process, particularly after small changes, is often impeded by pumping or other hydrologic factors. Preseismic changes are seldom

\footnotetext{
${ }^{1}$ Department of Geosciences, National Taiwan University, Taipei 106, Taiwan. E-mail: ypc@ntu.edu.tw

2 Atomic Energy Council, Yonghe, Taipei 234, Taiwan.

3 Department of Bioenvironment Systems Engineering, National Taiwan University, Taipei 106, Taiwan.
} 
reported (Roeloffs and Quilty, 1997; Koizumi and Tsukuda, 1999), and the supporting evidence and underlying mechanism of their relations to fault deformation or earthquakes are not clear (KING et al., 2000).

While studies pertaining to the distribution and process of earthquake-related hydrologic phenomena are hampered by limited data, preliminary clues have been obtained by examining groundwater level changes recorded by a dense monitoring well network in the vicinity of a thrust fault ruptured during a large earthquake in Taiwan. Here we use monitoring records before, during, and after the earthquake to enhance our understanding of the spatial and temporal distribution as well as the possible mechanisms of groundwater level changes induced by thrust faulting.

\section{Earthquake and Monitoring Wells}

On 21 September 1999, an earthquake of $M_{W} 7.6$ occurred near the town of Chi-Chi in central Taiwan at 1:47 a.m. local time. The hypocentral depth was estimated to be $10 \mathrm{~km}$ (SHIN et al., 2000). The best fitting focal mechanism has a nodal plane with a strike of $5^{\circ}$, a dip of $34^{\circ}$ and a rake of $65^{\circ}$ (CHANG et al., 2000; KAO and CHEN, 2000). As shown in Figure 1, widespread surface rupture resulted from thrusting along the Chelungpu fault extended approximately $100 \mathrm{~km}$ in the north-south direction (ANGELIER et al., 2003). The hanging wall is on the east side of the thrust fault. Field investigations and GPS data indicated that the hanging wall moved as much as $10.1 \mathrm{~m}$ laterally and $8 \mathrm{~m}$ vertically. In contrast, up to $1.5-\mathrm{m}$ lateral displacement and $0.26-\mathrm{m}$ vertical displacement were observed in the footwall (Yu et al., 2001).

In the coastal plain of Taiwan, the second generation network of monitoring wells had been installed since 1992 for improving groundwater resource management. At the time of the Chi-Chi earthquake, 377 monitoring wells were operational in Taiwan. In the vicinity of the seismogenic fault, all wells, except one, are located in the footwall (west side) of the fault. Groundwater level is recorded by the digital data logger at one-hour interval. Some wells equipped with the analog data logger also provide continuous records. All of the monitoring wells were screened in highly permeable sand or gravel layers. Any changes of groundwater level in the aquifer can, therefore, be quickly reflected by changes of water level in the monitoring well.

\section{Spatial Distribution of Coseismic Groundwater Changes}

Coseismic changes of groundwater level in central western Taiwan due to the Chi-Chi earthquake have been discussed by CHIA et al. (2001) and WANG et al. (2001). The mechanisms of these coseismic changes have been discussed by LEE et al. (2002), WANG et al. (2003), Koizumi et al. (2004) and Lai et al. (2004). Two types of coseismic changes of water level were observed: oscillatory changes and persistent changes. 


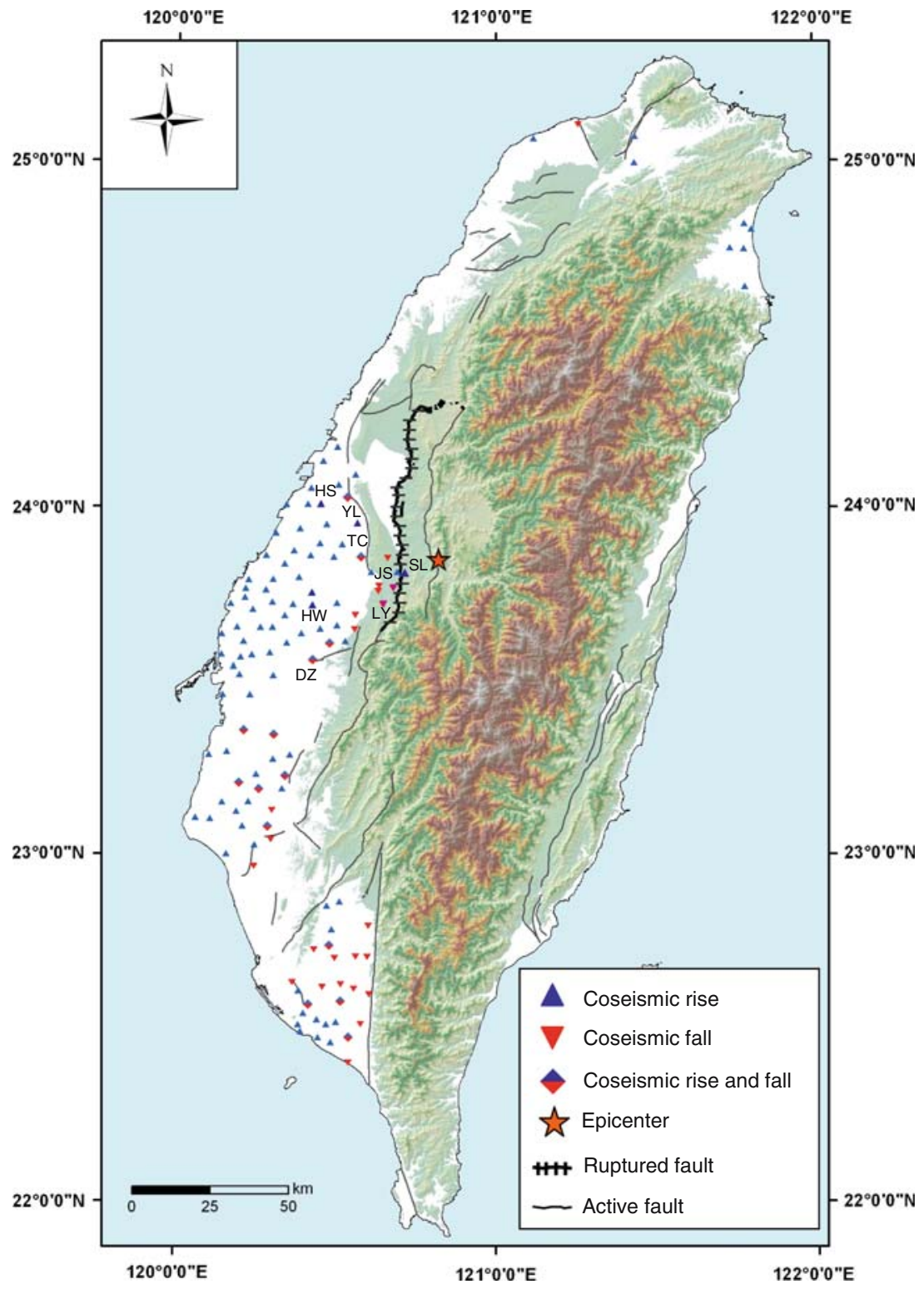

Figure 1

Map of Taiwan showing the spatial distribution of 276 wells located at 126 monitoring stations where coseismic groundwater level rises and falls were observed during the $\mathrm{M}_{\mathrm{W}}$ 7.6 Chi-Chi earthquake on September 21, 1999.

Oscillatory coseismic changes, recorded on analog records, were the response of water column in the well and pore pressure in the aquifer to passing earthquake waves (COOPER et al., 1965; Liu et al., 1989). The amplitude of oscillatory changes diminished shortly after the earthquake. Persistent coseismic changes have been proposed to be the 
response of formation fluid pressure to shear strain due to the redistribution of stress field resulted from fault movement (MuiR-Wood and KING, 1993; Ge and Stover, 2000). It is analogous to the response of pore pressure in soils to shear strain under an undrained triaxial test (WANG, 1997).

Of the 377 monitoring wells, persistent coseismic groundwater level changes were observed in 276 wells during the Chi-Chi earthquake. Figure 1 illustrates spatial distribution of coseismic groundwater level rises and falls based on hourly records of 276 wells at 126 monitoring stations in the coastal plain of Taiwan. Of those, 203 wells at 80 stations are located within $50 \mathrm{~km}$ from the thrust fault. Included are a coseismic rise of $7.42 \mathrm{~m}$ and a coseismic fall of $11.09 \mathrm{~m}$ (Figs. 2a and 2b), the largest changes ever documented.

It is noticed that, in the footwall of the seismogenic fault in central western Taiwan, coseismic falls were primarily observed at the stations near the ruptured segment. In contrast, coseismic rises prevailed at the stations away from the fault. At some stations in the transition area, both coseismic rises and falls were observed in wells of different depths. Similar distribution patterns were also observed in the footwall of the unruptured segment of the thrust fault in southwestern Taiwan as well as another active fault in southern Taiwan. There is a general trend in the variation of the magnitude of coseismic water level change with hypocentral distance, as shown in Figure 3. The
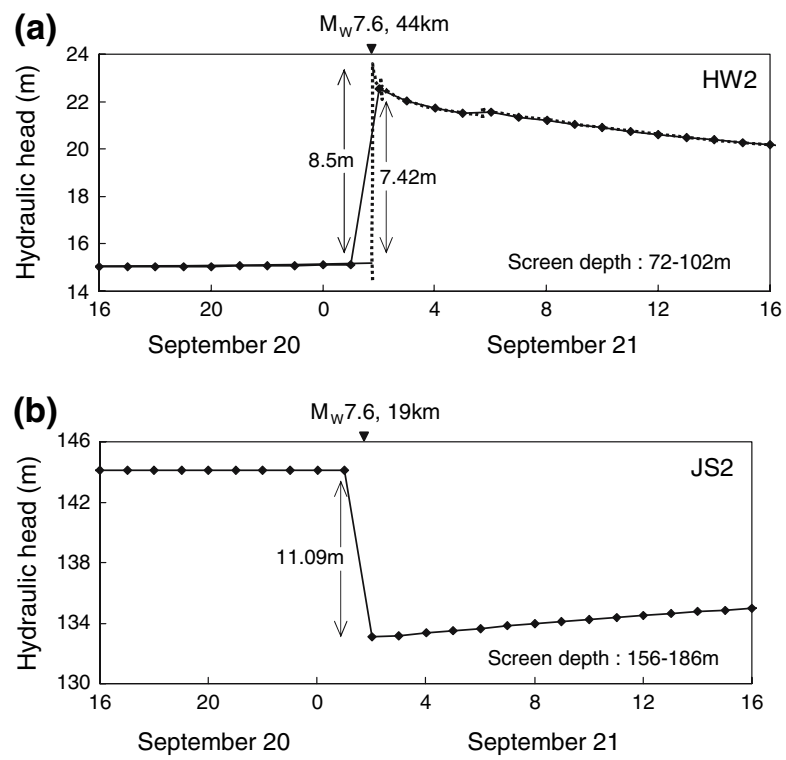

Figure 2

The largest coseismic rise and coseismic fall of groundwater level observed during the earthquake. Hypocentral distances are denoted on top of each panel. (a) Hourly records (solid line) of the HW2 well showing a coseismic rise of $7.42 \mathrm{~m}$ from 1 a.m. to 2 a.m., while analog records (dotted line) showing a rise of $8.5 \mathrm{~m}$ at 1:47 a.m. (b) Hourly records of the JS2 well showing a coseismic fall of $11.09 \mathrm{~m}$. 


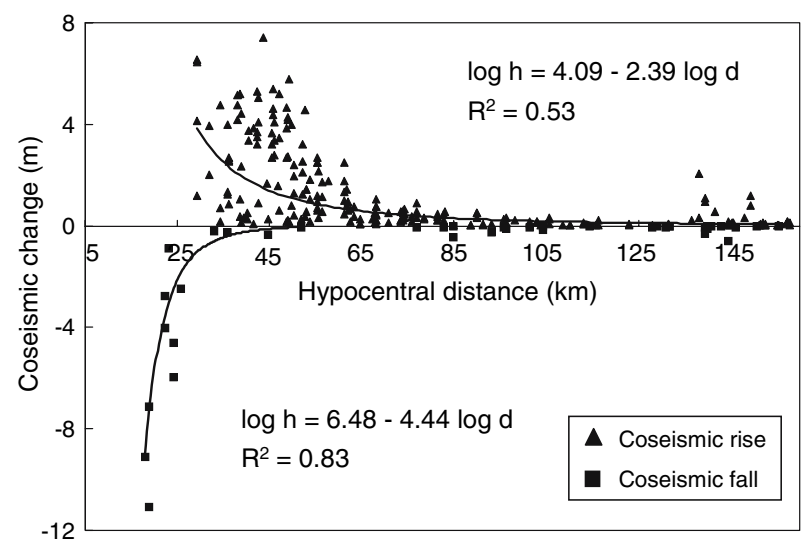

Figure 3

Coseismic groundwater level rise and fall versus hypocentral distance. Here coseismic changes in unconfined aquifers were excluded because they failed to represent the actual changes.

equation of the best-fit regression curve for the scatter plot of coseismic fall versus hypocentral distance up to $70 \mathrm{~km}$ is $\log h=6.48-4.44 \log d$, where $h$ is the magnitude of the coseismic change in meters and $d$ is the hypocentral distance in kilometers. The squared correlation coefficient $\left(\mathrm{R}^{2}\right)$ of 0.83 indicates a good correlation between coseismic fall and distance from the hypocenter in the vicinity of the thrust fault. The coseismic fall becomes considerably small beyond a hypocentral distance of $70 \mathrm{~km}$.

The equation of the best-fit regression curve for the plot of coseismic rise against hypocentral distance is $\log h=4.09-2.39 \log d$, with a squared correlation coefficient of 0.53. This suggests a moderate correlation between coseismic rise and hypocentral distance. As shown in Figure 3, large rises were observed primarily at stations located between $30 \mathrm{~km}$ and $60 \mathrm{~km}$ from the hypocenter. Nevertheless, the magnitude of coseismic rise at these multiple-well stations changes drastically with depth. While the rise diminishes gradually beyond $60 \mathrm{~km}$, moderate rises were observed in six wells beyond $130 \mathrm{~km}$. All of these six wells are located in northern Taiwan, implying that the redistributed stress induced by thrust faulting may concentrate in certain areas far from the seismogenic fault. Seismic shaking of the saturated porous medium provides another possible way of explaining the occurrence of coseismic rise at a distance from the epicenter (MonTGOMERY and MANGA, 2003).

\section{Postseismic Changes of Groundwater Level}

The recovery of groundwater level in response to coseismic changes began immediately after the earthquake in most wells. The recovery process in an aquifer was controlled primarily by groundwater flow, and the recovery rate of coseismic change 
varied with the confining condition of an aquifer. In a confined aquifer, the recovery process of coseismic change could last for several weeks to a few months (Fig. 4a). The coseismic change in a confined aquifer, defined as the water level change from 1 a.m. to
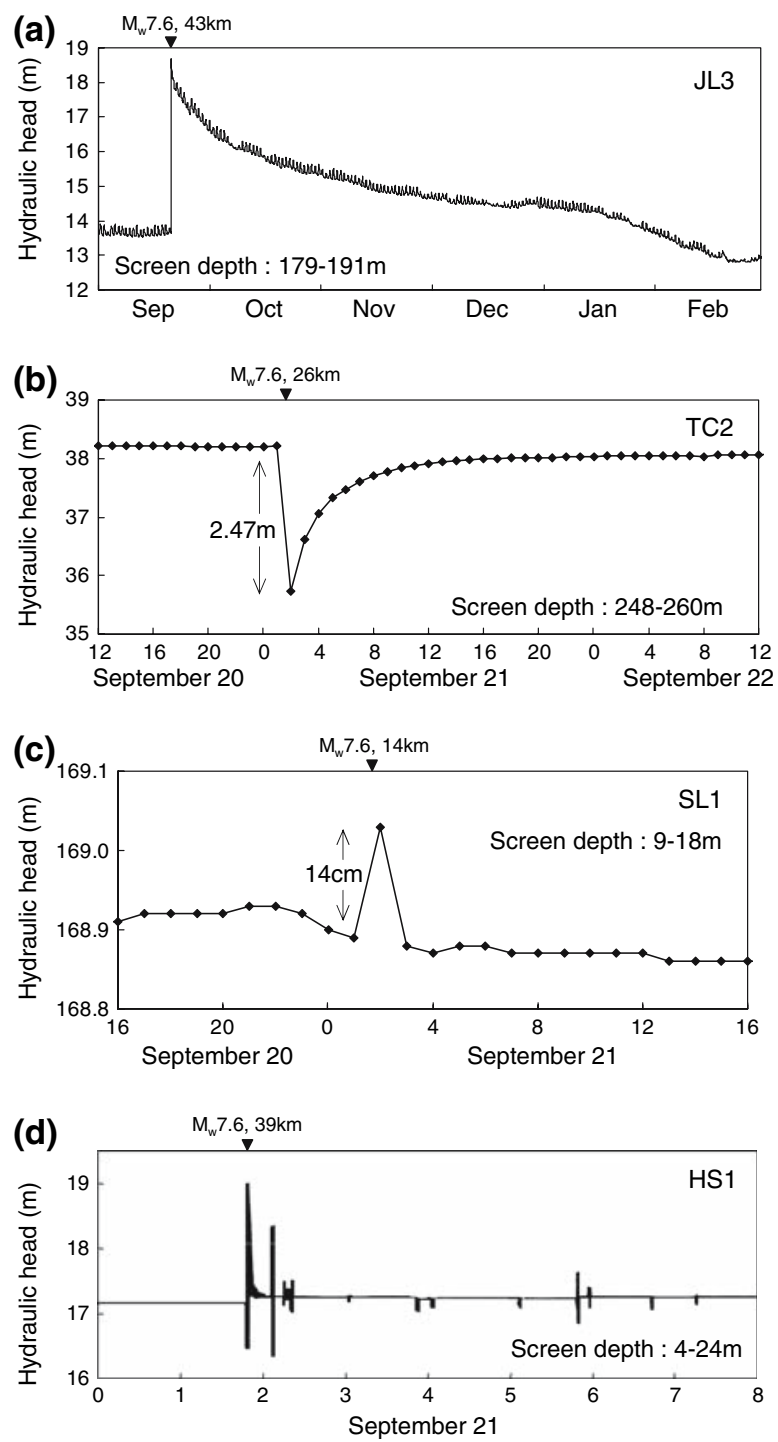

Figure 4

Temporal changes of groundwater levels under various confining conditions after the earthquake. (a) Recovery of water level in the JL3 well approximately 5 months after a coseismic rise in a confined aquifer. (b) Recovery of water level in the TC2 well approximately 16 hours after a coseismic fall in a partially confined aquifer. (c) Recovery of water level in the SL1 well within one hour after a coseismic rise in an unconfined aquifer. (d) Analog records at HS1 showing recovery in approximately 15 minutes after coseismic rise in an unconfined aquifer. 
2 a.m. September 21 on hourly records, is close to the actual coseismic change at 1:47 a.m. on analog records (Fig. 2a).

On the contrary, the recovery rate of groundwater level in an unconfined or partially confined aquifer is considerably faster. For instance, the TC station is located in a groundwater recharge area. The shallow well, TC1, was installed in an unconfined aquifer while the deep well, TC2, was installed in an aquifer confined partially by the overlying silty layer. The coseismic change in TC2 took 16 hours to recover to a steady level (Fig. 4b). In an unconfined aquifer, such as SL1, a pulse-like water level change is typically observed on hourly records, indicating the recovery process was completed within one hour after the coseismic change (Fig. 4c). On analog records, however, most actual coseismic changes at 1:47 a.m. in the unconfined aquifer were recovered within tens of minutes after the mainshock (Fig. 4d). Consequently, only a fractional or unnoticeable water level change could be observed at 2 a.m. on hourly records. As the recovery rate of coseismic change depends on the confining condition of an aquifer, the variation pattern of a coseismic water level change and its recovery process could be a potential criterion for characterizing the degree of aquifer confinement.

Most monitoring stations are composed of 2 to 5 wells screened at different depths, ranging from $14 \mathrm{~m}$ to $300 \mathrm{~m}$. Records of these multiple-well stations revealed clues to the variation of coseismic change in the vertical direction as well as to the occurrence of cross-formational flow in the subsurface after the earthquake. They also provide field evidence for interpreting earthquake-related groundwater level anomalies.

First, the magnitude of coseismic change fluctuated in wells at different depths. For instance, the coseismic rise at the YL station, as shown in Figure 5a, varies from $6.55 \mathrm{~m}$ in YL1 at the depth of $69 \mathrm{~m}$ to $1.2 \mathrm{~m}$ in YL4 at $198 \mathrm{~m}$. The DZ station recorded a coseismic fall of $9 \mathrm{~cm}$ at DZ2, but a coseismic rise of $28 \mathrm{~cm}$ and $14 \mathrm{~cm}$ at DZ1 and DZ4, respectively (Fig. 5c). Such a difference in the vertical direction provides a possible explanation for difficulties in matching coseismic groundwater level changes with volumetric strain changes estimated from fault displacement based on simple dislocation models (IgARASHI and WaKiTA, 1991; Quilty and RoelofFs, 1997; GRECKSCH et al., 1999).

Second, postseismic anomalous changes of groundwater level at some multiple-well stations revealed the occurrence of cross-formational flow in the subsurface after the earthquake. Regional groundwater flow is considered a steady-state condition before the earthquake. The variation of coseismic changes at different locations and depths, however, initiated a transient flow in both lateral and vertical directions after the earthquake. For instance, the permeable layers tapped by YL2 and YL3 are hydraulically interconnected as evidenced in Figure 5a by the overlap of their groundwater levels before the earthquake. It is noted that the coseismic rise was $6.46 \mathrm{~m}$ in YL2, but only $4.12 \mathrm{~m}$ in YL3. The hydraulic gradient induced by different coseismic changes drove groundwater flow downward, resulting in a decline of water level in YL2 and a rise in 

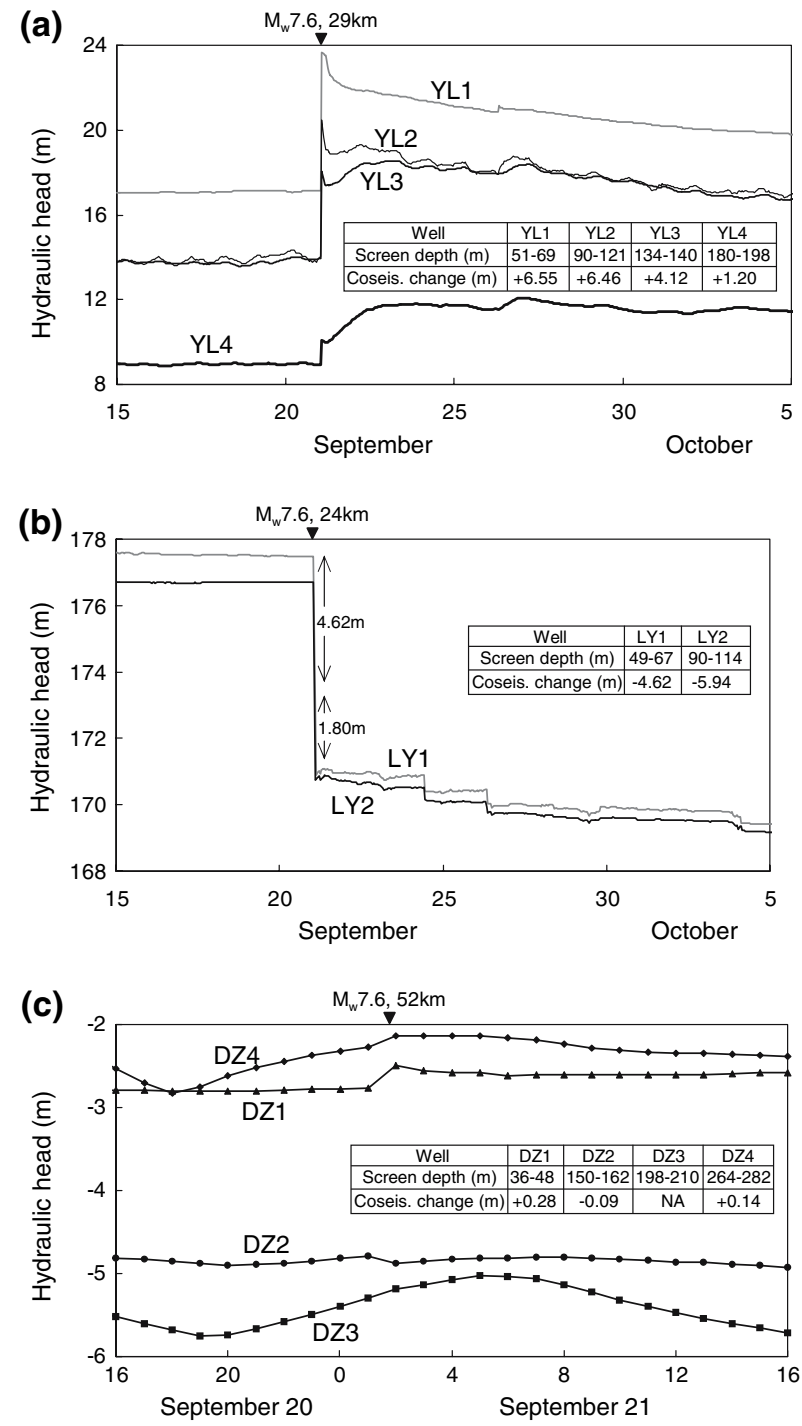

Figure 5

Temporal change of groundwater levels in different depths at three multiple-well stations. (a) The YL station. The coseismic rise fluctuates in wells of different depths. The water levels at YL3 and YL4 continued to rise for a few days after the earthquake. (b) The LY station. After a coseismic fall of $4.62 \mathrm{~m}$ and a postseismic fall of $1.80 \mathrm{~m}$, the water level at LY1 approached that of LY2. (c) The DZ station. The cosiesmic rise appeared in DZ2 while coseismic falls were observed in DZ1 and DZ4. The coseismic change in DZ3 cannot be identified.

YL3 until they came close again four days after the earthquake. The continued rise of groundwater level after a coseismic rise, similar to YL3, was also observed in YL4 and several other wells. 
The confining conditions of some aquifers near the surface rupture zone may have been changed by the earthquake. For instance, both LY1 and LY2, located $5 \mathrm{~km}$ from the ruptured segment, were artesian wells before the earthquake (Fig. 5b). Instead of a gradual rise after the coseismic fall, the groundwater levels declined further for several months after the earthquake. This phenomenon implies that subsurface fracturing may have been developed through the artesian aquifer during the earthquake. Crossformational flow could be generated when the confinement of the aquifer was breached, resulting in a rapid dissipation of pore water pressure after the earthquake (ROJSTACZER et al., 1995; KING et al., 1999). Both wells were no longer artesian after the earthquake.

\section{Preseismic Changes of Groundwater Level}

Several abnormal changes of groundwater level, observed from tens of minutes to a few months before the Chi-Chi earthquake, have been identified. Further examination indicated that these changes were likely to be associated with local pumping, rainfall, or improper data management, except a rapid decline of groundwater level immediately before the earthquake in the SL1 well (Fig. 4c).

The SL1 well, located approximately $1.5 \mathrm{~km}$ east of the ruptured fault, is the only monitoring well installed in the hanging wall. It was placed in a shallow unconfined aquifer. The water level in SL1 had not been interfered by pumping since the beginning of monitoring in 1997 until the end of 2000. At the beginning of each recession (falling) stage during this period, the water level usually declined slowly with the rate of decline increasing gradually or remaining steady. The decline had never exceeded $3 \mathrm{~cm}$ during the first 3 hours in all recession stages, except for the one right before the Chi-Chi earthquake (Fig. 6).

It is observed that, after rainfalls from September 15 to 19,1999 , the water level in SL1 rose gradually on September 19 and 20, as shown in Figure 7, but declined $4 \mathrm{~cm}$ abruptly over a 3-hour period right before a 14-cm pulse-like coseismic rise. By

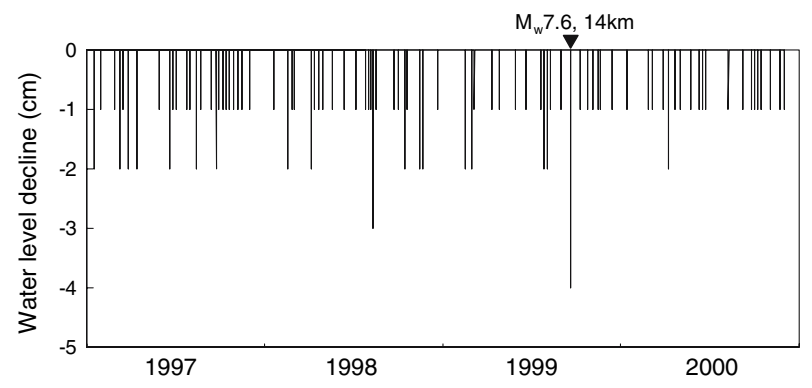

Figure 6

Water-level decline in the SL1 well during the first 3 hours in recession stages from 1997 to 2000. The largest decline, $4 \mathrm{~cm}$, appeared right before the Chi-Chi earthquake. 


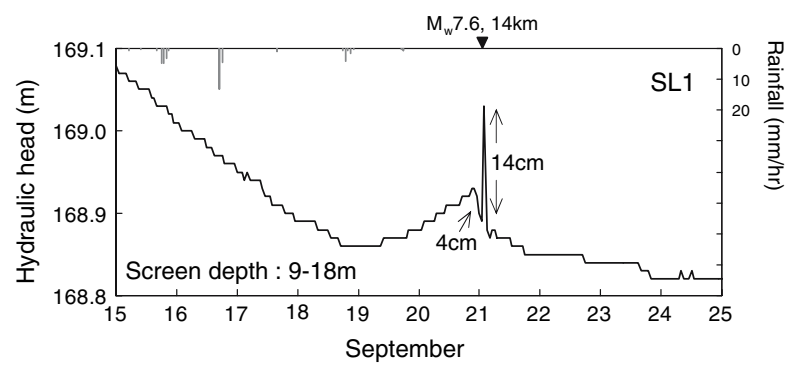

Figure 7

Ten-day records of groundwater level in the SL1 well showing a 4-cm decline from 22:00 September 20 to 1:00 September 21 immediately before a 14-cm coseismic rise at 2:00 September 21 (also shown in Fig. 4c). The decline continued after the earthquake and the rate of decline decreased gradually when the pulse-like coseismic rise and its recovery were ignored.

ignoring coseismic change and its recovery, the rate of water level decline decreased gradually during the beginning of the recession starting from 22:00 September 20. The $4-\mathrm{cm}$ decline of groundwater level immediately before the earthquake and the unique decreasing rate of decline at the beginning of the recession stage, therefore, becomes a unique hydrologic anomaly in SL1. Whether the decline is caused by dilatational deformation in the hanging wall right before the earthquake remains to be investigated.

\section{Conclusions}

The comprehensive data recorded at monitoring well stations during the $\mathrm{M}_{\mathrm{w}} 7.6$ Chi-Chi earthquake provide a preliminary framework of regional distribution of coseismic groundwater level changes. The spatial distribution of observed coseismic change may reflect the redistribution of stress field in the shallow subsurface induced by the displacement of seismogenic fault. Such a complex distribution of coseismic changes is not expected to be consistent with volumetric strains calculated from a simple dislocation model. It is desirable to develop a more sophisticated model, taking into consideration aquifer characteristics and other geologic conditions, to describe coseismic changes induced by fault displacement.

Postseismic groundwater level changes are essentially the subsurface hydrologic responses to various coseismic changes. Records from multiple-well stations revealed the importance of vertical confinement and cross-formational flow in the water level recovery after coseismic changes, providing a basis for interpreting anomalous changes of groundwater level after the earthquake. Moreover, the coseismic change and the postseismic recovery process could be considered a natural hydraulic testing for characterizing the confining condition or estimating hydraulic parameters of aquifers. 
An anomalous decline of groundwater level was observed in the hanging wall immediately before the earthquake, although the underlying mechanism of the phenomenon is not clear. As large earthquakes occur frequently in Taiwan and the monitoring well network continues to expand, more earthquake-related water level records will be available to facilitate further investigations.

\section{Acknowledgements}

We gratefully acknowledge access to monitoring records and hydrogeologic information of the Water Resources Agency and the Central Geological Survey of Taiwan. This work is supported by the National Science Council of Taiwan (NSC-94-2116-M002011) and the Water Resources Agency (MOEAWRA0950187).

\section{REFERENCES}

Angelier, J., Lee, J. C., Chu, H. T., and Hu, J. C. (2003), Reconstruction of fault slip of the September 21st, 1999, Taiwan Earthquake in the asphalted surface of a car park, and co-seismic slip partitioning, J. Struct. Geol. 25, 345-350.

Bakun W. H. and Lindh, A. G. (1985), The Parkfield, California Earthquake prediction experiment, Science 229, 619-624.

BREDEHOEFT, J. D. (1967), Response of well-aquifer systems to earth tides, J. Geophys. Res. 72, 3075-3087.

Chang C.H., Wu, Y.M., Shin, T.C., and WAng C.Y. (2000), Relocation of the 1999 Chi-Chi earthquake in Taiwan, Terrestrial, Atmos. and Ocean. Sci. 11, 581-590.

ChIA, Y.P., WANG, Y.S., ChIU, J.J., and LiU, C.W. (2001), Changes of groundwater level due to the 1999 Chi-Chi earthquake in the Choshui River alluvial fan in Taiwan, Bull. Seismol. Soc. Am. 91, 1062-1068.

Cooper, H. H., Jr., Bredehoeft, J. D., Papadopulos, I. S., and Bennett, R. R. (1965), The response of wellaquifer systems to seismic waves, J. Geophys. Res. 70, 3915-3926.

GE, S. and Stover, S. C. (2000), Hydrodynamic response to strike- and dip-slip faulting in a half-space, J. Geophys. Res. 105, 25513-25524.

Grecksch, G., Roth, F., and KüMPel, H.J. (1999), Co-seismic well-level changes due to the 1992 Roermond earthquake compared to static deformation of half-space solutions, Geophys. J. Int. 138, 470-478.

IGARASHI, G. and WAKITA, H. (1991), Tidal responses and earthquake-related changed in the water level of deep wells, J. Geophys. Res. 96, 4269-4278.

KAO, H. and CHEN, W.P. (2000), The Chi-Chi earthquake sequence: Active, out-of-sequence thrust faulting in Taiwan, Science 288, 2346-2349.

King, C.-Y., Azuma, S., Igarashi, G., Ohno, M., Saito, H., and Wakita, H. (1999), Earthquake related waterlevel changes at 16 closely clustered wells in Tono, Central Japan, J. Geophys. Res. 104, 13073-13082.

King, C.-Y., Azuma, S., Ohno, M., Asai, Y., He, P., Kitagawa, Y., Igarashi, G., and Wakita, H. (2000), In search of earthquake precursors in the water-level data of 16 closely clustered wells at Tono, Japan, Geophys. J. Int. 143, 469-477.

Kissin, I.G., Belikov, V.M., and Ishankuliev, G.A. (1996), Short-term groundwater level variations in a seismic region as an indicator of the geodynamic regime, Tectonophysics 265, 313-326.

Koizumi, N. and Tsukuda, E. (1999), Preseismic changes in groundwater level and volumetric strain associated with earthquake swarms off the east coast of the Izu Peninsula, Japan, Geophys. Res. Lett. 26, 3509-3512.

Koizumi, N., LaI, W.-C., Kitagawa, Y., and Matsumoto, N. (2004), Comment on "Coseismic hydrological changes associated with dislocation of the September 21, 1999 Chi-Chi earthquake, Taiwan" by Min LEE et al., Geophys. Res. Lett., 31, L13603, doi: 10.1029/2004GL019897. 
Lai, W.-C., Koizumi, N., Matsumoto, N., Kitagawa, Y., Lin, C.-W., Shieh, C.-L., and Lee, Y.-P. (2004), Effects of seismic ground motion and geological setting on the coseismic groundwater level changes caused by the 1999 Chi-Chi earthquake, Taiwan, Earth Planets Space 56, 873-880.

LeE, M., Liu, T.K., MA, K.F., and Chang, Y.M. (2002), Coseismic hydrological changes with dislocation of the September 21, 1999 Chi-Chi earthquake, Taiwan, Geophys. Res. Lett. 29, doi: 10.1029/2002GL015116.

Liu, L.B., Roeloffs, E., and ZhEng, X.Y. (1989), Seismically-induced water level fluctuations in the Wali well, Beijing, China, J. Geophys. Res. 94, 9453-9462.

Montgomery, D. R. and Manga, M. (2003), Streamflow and water well responses to earthquakes, Science 300, 2047-2049.

MuiR-Wood, R. and King, G. C. P. (1993), Hydrologic signatures of earthquake strain, J. Geophys. Res. 98, 22035-22068.

Quilty, E.G. and RoEloffs, E.A. (1997), Water-level changes in response to the 20 December 1994 earthquake near Parkfield, California, Bull. Seismol. Soc. Am. 87, 310-317.

Roeloffs, E.A. (1998), Persistent water level changes in a well near Parkfield, California, due to local and distant earthquake, J. Geophys. Res. 103, 869-889.

Roeloffs, E.A. and Quilty, E. (1997), Water level and strain changes preceding and following the August 4, 1985 Kettleman Hills, California, Earthquake, Pure Appl. Geophys. 149, 21-60.

Rojstaczer, S., Wolf, S., and Michel, R. (1995), Permeability enhancement in the shallow crust as a cause of earthquake-induced hydrologic changes, Nature 373, 237-239.

Shin, T.C., Kuo, K.W., LeE, W.H.K., Teng, T.L., and Tsai, Y.B. (2000), A preliminary report on the 1999 Chi-Chi (Taiwan) earthquake, Seismol. Res. Lett. 71, 23-29.

WAKITA, H. (1975), Water wells as possible indicators of tectonic strain, Science 189, 553-555.

WANG, C. Y., Cheng, L. H., Chin, C. V., and Yu, S. B. (2001), Coseismic hydrologic response of an alluvial fan to the 1999 Chi-Chi earthquake, Taiwan, Geology 29, 831-834.

Wang, C.Y., Dreger, D.S., Wang, C.H., Mayeri, D., and Berryman, J. G. (2003), Field relations among coseismic ground motion, water level change and liquefaction for the 1999 Chi-Chi $\left(M_{w}=7.5\right)$ earthquake, Taiwan, Geophys. Res. Lett. 30, doi: 10.1029/2003GL017601.

WANG, C. Y., WANG, C. H., and KuO, C. H. (2004), Temporal change in groundwater level following the 1999 $\left(M_{w}=7.5\right)$ Chi-Chi earthquake, Taiwan, Geofluids 4, 210-220.

WANG, H.F. (1997), Effects of deviatoric stress on undrained pore pressure response to fault slip, J. Geophys. Res. 102, 17943-17950.

Yu, S.B., Kuo, L.C., Hsu, Y.J., Su, H.H., Liu, C.C., Hou, C.S., Lee, J.F., Lai, T.C., Liu, C.C., Liu, C.L., Tseng, T.F., Tsai, C. S., and Shin, T.C. (2001), Preseismic deformation and coseismic displacements associated with the 1999 Chi-Chi, Taiwan earthquake, Bull. Seismol. Soc. Am. 91, 995-1012.

(Received June 1, 2007, revised November 12, 2007, accepted November 17, 2007)

Published Online First: February 1, 2008

To access this journal online:

www.birkhauser.ch/pageoph 